\title{
Economical and Social Effects on Retirement Salaries of Participants and Beneficiaries From the Jordanian Social Security System
}

\author{
Mustafa M. Soumadi ${ }^{1}$ \\ ${ }^{1}$ Department of Financial and Administrative Sciences, Balqa Applied University, Irbid University College, Irbid, \\ Jordan \\ Correspondence: Dr. Mustafa M. Soumadi, Assistant Professor-Department of Financial and Administrative \\ Sciences, Balqa Applied University, Irbid University College, P.O. Box 1293, Irbid, Jordan.
}

Received: May 10, 2020

doi:10.5430/rwe.v11n3p293
Accepted: June 14, 2020

Online Published: June 27, 2020

URL: https://doi.org/10.5430/rwe.v11n3p293

\begin{abstract}
The study aims to identify the reality of retirement salaries for the 1,200,000 insured employees at the social security network in Jordan, out of a total workforce of about 5,926,580, which means that $20 \%$ of the total number of employees is included in the social security system. The study aimed to make a comparison between the retirement salaries level and the cost of living level of the Jordanian family, which amounted to (854) JDs per month based on the spending and wages average at the Jordanian General Statistics Department, while the retirement salaries rate paid to the retirees of government and private sectors amounted to (494) JDs per month for the public sector and also (494) JDs per month for the family of private sector.

The study viewed the retirement salaries rates according to the various economical activities for the years (2015/2016) and the results showed that average retirement salaries for those eligible social security participants (493) JDs per month, while the average beneficiaries who currently receive retirements salaries is about (576) JDs per month and their number about $(193,763)$ thousand citizens. The study was also shocking as it turns out that retirement salary for the beneficiaries who receive retirement salaries now between (178) and (576) JDs, which means that many of the low beneficiaries segments and after (20) years of continuous service their retirement salaries don't reach the government-set poverty line of (339) JDs per month, and all salaries of participants who haven't reached the retirement age and the beneficiaries, the retirement salaries of $100 \%$ of them will not reach the sufficiency line or the average cost of living for the Jordanian family of (854) JDs per month. Study recommends the establishment of a higher wage council made up of economists, jurists, financial people, and representatives from the public and private sector, and the army, military, and security institutions to establish a fair wage system.
\end{abstract}

Keywords: fair pay, social security system, social security participants, social security beneficiaries, standard of living, sufficiency, workforce

\section{Introduction}

The idea of social security was based on providing a social and economical safety network for the Jordanian society, and provide a retirement system for the beneficiary citizens and their families who are participants in the retirement security systems and have reached age (45) for the early retirement and (60) years for regular retirement, in cases of death, total and partial disability, disease, and various work injuries, and it also includes the unemployment retirements cases and maternity salaries through the conditions listed in the social security act.

The study problem reside in the retirement salaries levels of social security beneficiaries and participants, where Social Security Corporation supposed to provide a safety network for retirees; particularly in Jordan. The retirement salary from security has become the basic and only one for the Jordanian family, where the family head depends on it to support the family and children after reaching the retirement age, due to the fact that salary isn't enough to spend on the basics, such as food and drink where most beneficiaries of the retirements salaries through the social security complain from the low salaries.

The study aims to achieve the following objectives:

-Identify the minimum level of retirement salaries for participants and beneficiaries from the social security system.

-Identify the basics that social security corporation used to build the retirement salaries levels of beneficiaries. 
-Identify the method used to develop a fair retirement salaries system for the social security system beneficiaries.

-The wages systems and levels should be equal to the cost of living averages for the Jordanian family.

-Unify the different wages system and the retirement salary systems at all different labor sectors.

The first social security law in Jordan was passed in 1978 and was first implemented in 2003. Social security almost considers the only corporation that includes a symbiotic insurance retirement system which aimed to protect all citizens economically and socially. This corporation has made progress in developing its systems and in investing the participants' funds which collect over the years, where the capital and investments of the social security corporation is estimated to (8.3) billion JDs. It's a government corporation but it's financially and managerially independent and doesn't receive any financial support from the Jordanian state.

In this summarized paper we will discuss some of the statistical figures for the salaries of security beneficiaries, according to the categories and types of divisions specified in the social security act, and to identify the social and economical effects on the society. It's also an attempt to inquire about some of the questions and concerns that are importance to all citizens residing on this homeland, and provide some suggestions and recommendations to correct some of the distortions in this system.

The importance of this study lies in the fact those retirements salaries are the basis for safe income of every human being, where working individuals must receive a retirement salaries that provide them and their families with a decent living; after reaching the retirement age. It's a sufficient income for individuals and their family, which parallel to the cost of living from food, drink, entertainment, health, education, without the need for anyone or having to borrow, with the need to find and establish a fair system of social security retirement salaries which is obligatory to the Social Security Corporation and other state sectors.

The study hypotheses represented in the following:

Salaries of retirees who benefit from the social security system are sufficient for the Jordanian family average cost of living

Most Jordanians benefit from the social security retirement salaries

All sectors of the workforce receive close averages of the retirement salaries upon reaching retirement age

There are basic civil salaries retirements that don't depend on the social security system and this system is complementary with the rest of retirement systems which everyone is entitled to participate in it

The retirement salaries for social security beneficiaries and retirees don't reach the sufficient level

\section{Research Methods}

\section{Reality of the Social System in Jordan:}

The Social Security Act in Jordan was first passed in 1978 as a temporary law no. 30, and then the permanent law no. 19 was passed in 2001 and followed by the amendments with law no. 26 of 2009, and then law no. 7 of 2010, until issuing the last law no.1 of 2014. The provisions of law also include the right of all working and non-working Jordanians to join social security system, as well as the self-employed persons, the employers, the solidarity partners who work at their facilities, and the Jordanians who work overseas.

\section{Social Security Objectives:}

- Secure the basic needs of the insured person and his family members by providing a stable income.

- Build positive relationships between the employees and employers.

- Deepen the social solidarity values in the society and distribute the income between the generations.

- Contribute to the economical and social development.

The Insurance Covered by the Social Security Act which Deserve Retirements Salaries and Financial Compensations:

- Old age retirement's salaries (60) and early retirement (45 years).

- Salaries of normal disability, total and partial compulsory, and death.

- Unemployment insurance salaries (3-6 months).

- Maternity insurance salaries (70 days). 


\section{Social Security Systems in some World Countries:}

The social solidarity or social security system is adopted among most governments of the world countries, where in Saudi Arabia the social security system represents the comprehensive network for insuring the salaries of retirees, and even the salaries of limited income and the poor.

Al-Jaloud stressed that social security works through three main objectives, first: solve the problems of poor families by offering a monthly salary, which is determined by the number of family members, second: raise standard of living for the family through a number of programs that were adopted by the guardian of the Two Holy Mosques, which also contribute to raising the standard of living for those poor families, and third: introduce the productive families programs for the purpose of transferring the social security beneficiaries from people in need of government support to employees who can support themselves and their families, through various economical projects that will be created according to the region environment and its products (Al-Jaloud, 2017).

The first Federal Social Security Act in the United States was enacted in 1935 under number (H.R. 7260) to introduce the public care system in cooperation with other states, which includes the old age benefits system, insurance salaries for the blinds, dependent children, paralyzed children, maternity care and childhood, public health, and the management of unemployment compensation laws, the establishment of a federal council to pass the laws and legislation and present it to the Senate and the Parliament, and review the salaries periodically and improve it with the change in standard of living. The law specified that U.S. citizens should not be excluded from the public care, and any government or private entity that doesn't enforce the law shall be punished by the law. The law details include the provision of salaries for those who have reached the old age, without looking to their service or work and the amount of salary for employees align with the length of service or the value of their salaries during the work period, but the law guarantees a minimum salary for all citizens without discrimination.

\section{Social and Economical Affects of Participants Salaries at the Security System}

The participants retirements salaries at the social security consider one of the social and economical security pillars for many of the Jordanian society, especially the class of old people who gave their lives to build this country who are our mothers, fathers, teachers, and scholars, they are the protectors of homeland from the Jordanian armed forces and the public security, in addition to the manufacturers, farmers, traders, and all type of labors from the hard employees who are the builders of this country.

Due to the fact that all the above categories has become involved in a retirement system linked to the social security, therefore its necessary to provide them with a decent life and give them a sufficient income, and even exceed the adequateness without needing anyone. During the review of beneficiaries and participants average salaries, it show that it's very low and some of it don't reach the poverty limit of 339 JDs per month; set by the government as indicated by this research. Therefore, salaries must be restructured for all the categories and establish a salary base that stand on the bare minimum limit to create the adequateness limit or the average cost of living which amounted to 854 JDs per month as an average for the wages (Family Expenditure Survey Report, 2015).

There is a need to improve the salaries of retirement retirees, especially the low and medium salaries; and in a very urgent way due to the economical and living circumstances that majority of the insurance retirees suffered from in specific, and the salaries of public and private sector employees in general, and also the failure of salaries to keep pace with the continuous increase in prices, which led to the attrition of purchasing value for retirees' salaries. President of Security Retirees Association Mr. Arabiyat pointed out that a large percentage of the security retirees their salaries are below the poverty line, pointing out the need for salaries to be adequate with the costs of living. In addition, the current temporary security law and the low level of salaries which has a minimum limit of (373) JDs and its average (503) JDs for the participants. The beneficiaries who now receive retirements also have a minimum salary of (164) JDs per month, where the average wage scale for this group is (291) JDs per month. Those retirees have initially low salaries and don't have other occupations to earn an additional income; therefore they are forced to go to the charity and Zakat institutions to seek help and financial assistance. If this shows anything, it indicates that social security law is unreasonable and salary levels are low, and it needs to be reviewed. This require from the government and the representatives and the senate of the national council, and also the social security corporation to work to improve the wage levels, and justify the participants and beneficiaries by increasing their retirement salaries to bring it to an adequate wage.

\section{Poverty and Unemployment Issues:}

Public information indicates that levels of unemployment and poverty are widening due to the economic recession that the country is going through, the constant increase in the prices of petroleum products despite its decline globally; at the present time and its effects on the Jordanian society, and the continuous and unfair increase in the taxes level by the 
government which affect the profits levels of private enterprise and the increase in inflation rates, and all of this is accompanied by high unemployment rates. The unemployment rate among males was $12.7 \%$, compared with $23.7 \%$ for females, where statistical results indicated that $50.9 \%$ of overall unemployed were high school graduates or more, and $49.1 \%$ of all unemployed had lower educational qualifications than the secondary school student. The proportion of unemployed varied according to the educational level and gender, where it amounted to $22.2 \%$ for unemployed male who hold a bachelor's degree, compared with $76.7 \%$ for females.

The highest unemployment rate was recorded for the (15-19 and 20-24) age groups, where the average amounted to (42.6\% \& 33.0\%) respectively (Unemployment Report, 2015). Employees face many challenges in the labor market, one of those is the intense competition that they face from the migrant employees which has inflated considerably, where migrant employees amounted to $(130,560)$ or $12 \%$ of the total workforce who are officially registered and hold a work permits. It's known that the actual number of migrant employees is much higher who they constitute about twice the number of unemployed Jordanian employees. This dilemma needs to be solved and it's not enough to talk about the unwillingness of Jordanian employees to work in some of the occupational sectors, but the causes of this phenomenon should be sought and addressed. Some of those reasons related to the salaries of employees at factories, craft, and service professions which don't exceed the minimum wage level, but many of these companies' owners, especially the private schools refuse to pay the worker even the minimum wage of (220) JDs per month which was set by the government recently.

Its notable that despite the changes in the labor market and the high living cost levels, the salary levels of beneficiaries who receive retirements now are low, where the minimum retirement salaries is (178) JDs per month and the average retirement salaries for beneficiaries don't exceed (576) JDs. This doesn't match the cost of living averages for a family of five, which is about (854) JDs per month and doesn't even reach the adopted poverty line of (339) JDs per month, for the average Jordanian family. This means that more than $26 \%(38,456)$ of the total beneficiaries and recipients of social security salaries $(147,908)$ receive salaries less than (339) JDs, which also means that $26 \%$ of the social security retirement salaries are below the poverty line and approximately $89 \%$ below the sufficiency limit of (854) JDs per month.

All of this put pressure on the citizens, especially the retirees due to their old age and their inability to generate an additional incomes, which leads to the disintegration of some families, swerve of some young people, student dropping out of school, high crime rates, and the deterioration of citizen's health status as a result of the lack of proper nutrition.

Islam's View of Social Security as a Symbiotic Insurance System for Society:

Islam called for the achievement of social solidarity as one of the foundations, where its possible through it to achieve decent life for the needy in society, and accordingly has created many forms of religious giving in order to achieve this solidarity, which include: Zakat, charity, Waqf, infidels, and vows where these giving forms aren't only limited to meet the basic needs of human being, but also to achieve the sufficiency and wealth limits.

Islam has pushed to preserve and protect the five necessities which are: money, soul, mind, breed or birth, and the religion, where the preservation of offspring and mind consider the basics of these necessities which can only be achieved if the Muslims secure for themselves the mind, body, and religion, since the decent life must be provided from food, clothing, drink, health, and education, therefore how can this be done if the salaries aren't provided to secure all expenses and living costs. It's essential that average retirement salaries for the beneficiaries of social security reach the sufficient limit or the fair pay.

The General Objectives that Many Economists Agreed on After Studying the Islamic Economic System (Al-Zubair, 1976):

- Ensure a minimum limit of living for every member of the Muslim community that guarantees the decent life (Social Security).

- Achieve the economical strength and pride of society to ensure the development and production of comprehensive economic that provides rewarding economical returns, without depending on others (Balanced and Comprehensive Development).

- Achieve the equitable balanced income and wealth inequality between people (social balance)

Securing a minimum limit of the decent living doesn't mean the subsistence limit (Absolute poverty line) that keeps the Muslim in need and destitution, where the individuals always afraid and fight to keep the death away them and their families. The limit of sufficiency is higher than the subsistence limit and means (ensuring a decent life for the individuals and their families, which include food and sustenance, clothing, housing, health, and education that 
guarantee them to stop asking the help from other people. This responsibility lies on the entire Muslim community and on the state which must assess this limit, implement it, adhere to it, and commit to it by the employers and those who have the authority to determine the salaries and wages. The Prophet Mohammad (PBOH) said, "Whoever work for us and have no home, he should get a house, if he wasn't married, he should get a wife, he hasn't a servant, he should get one, and if he has no pack-animal, he should get one." (Directed by Abu Daoud, 149, 2945), and he also said "Give the employees their wages before their sweat dries up".

The sufficiency limit or reward is a legitimate right for all members of the society when they become unable to achieve the sufficient income for reasons beyond their control, such as old age, illness, or lack of job opportunities which the responsibility of the society and the state to establish the laws and legislations, and specify in it the wages that guarantee those people a decent standard of living that catch them up with the others. Its an average fair pay or sufficient wage limit that isn't unstable where it get develop, change, and exchange whenever people's needs change, societies' accession, and rise of overall level of prices which should be adjusted and increased gradually; periodically and continuously. Omar said, may Allah bless him "If you give, give enough" and Ali said, may Allah bless him" (God has imposed on the rich from their money, whatever is enough for the poor).

\section{Determining the Actual Fair Pay of Employees:}

To identify the sufficient wage, it showed that is determined by measuring the cost of living for the average households in the society based on the individual's essential and improved needs as a base for wages in the public and private sector, and at the base of participants and beneficiaries of social security. After that, the fair pay, equivalent wage, or the benefit value will be determined under the normal conditions of the supply and demand market, at the public sector with the sufficient wages plus the wage increase at a rate equal to the personal allowances, as a result of the experience, specialization, degree, and family allowance. This wage will then be linked to the annual inflation rate or the increase rate of living cost prices to be adjusted, at the beginning of each year to reach the Islamic or actual wages that must be determined, as mentioned earlier by specialized independent and neutral committees which are represented by the state and the experts of economy, legislation and law. It's possible to divide it as follows: (Samadi, 2012)

Fair pay $($ actual $)=$ sufficiency limit $+($ basic wage + other bonuses $) *$ annual change rate at the general prices level (JDs)

- Fair (Actual) Wage: the wage paid to an employee represented by the sufficiency salary + personal allowances of individual as a result of experience, specialization, degree, family allowance + the annual increase in prices rate of goods and services.

- Basic wage: the wage basis that determined by the classification and degree of employee (profession allowance) which doesn't include personal allowances, insurance, security, and specialty allowance.

- Sufficiency Limit: the average cost of living for the family that consist of goods and services groups (restaurant, drink, clothing, dwelling, accessories, health, education and transportation).

- Change rate in the prices of goods and services: it can be calculated by identifying the price index of goods and services, and through it will find the change that occurs on the wage levels (the difference between the nominal wage index and real wages), where it shows the change rate in wage levels over a certain period of time compared with another period, as well as the change that occurs on the living expenses between the base period and the measurement period associated with the annual increase in goods and services.

- Worker Productivity: it projected by the scarcity of specialization and work type, and is known as the specialization allowance.

- Wife and Children Allowance: It must be determined by the average cost of wife's and child's maintenance, and can be determined at the time of measuring the cost of living averages for the family, where the wife's maintenance differs from the child support and this less than adolescence support.

- Other allowances (housing allowance, health insurance, education+ work difficulty+ overtime+ moving and transportation, and others).

Whenever we calculate the actual wage, the worker's wage must reach the sufficiency wage as a minimum limit for all employees in the state, and it must be a fair wage with no less than his partner wage at the private sector. If the wages and salaries committee is independent and relies on objective criteria, it will come out with a fair pay system that is fair to the worker and doesn't mistreat the state treasury. Its necessary to follow legitimate and objective constraints, such as justice constraint which is base on giving everyone their right and whatever they deserve, and the constraint that achieve the interest of individual and adopt the criteria of justice and the middle distance to calculate the cost of needs, 
necessities, and improvements (Abu Al-Fatouh, 2004), and the personal, occupational, and family allowance systems for anyone who works for the state. Whenever making an assessment for the employees' wages at the public and private sector, it might be a difference in the pay levels since justice and equity don't mean equality.

The different wages levels are due to a number of reasons, which include: (Rababah, 1999, p. 49-50)

- The cost of living for the area in which the individual lives.

- Worker productivity, which is the ratio between a particular production and the amount of work and effort that has been made to achieve it.

- Nature of work and the physical and mental capabilities required to accomplish it.

- The efficiency of worker, which means the required quantity and quality, and the skill and experience required to complete the work.

- Number of family members and dependants of employees.

- Specialization and type of certificate held by the worker and the scarcity level of his specialization.

\section{Retirement Systems:}

Different retirement systems implemented globally, for example in the United States of America there are two separate systems:

\section{First: Civil Retirement System}

It's based on the basis of participation in the service and will deduct an amount from the employee's salary to be entered into a private savings account, and the employer pays a portion of this amount also for this purpose and after reaching the retirement period, which isn't associated with the age but with the employment period and its usually between (16-20) years. A retirement salary that befit the employees will be granted to them to live a comfortable sufficient life without asking anyone, where this represent a worker right at the institution, company, army, or government who spent his life at the public or private institution. These companies and institutions have gained thousands of JDs as a result of the effort of this employee throughout his long service.

\section{Second: Social Security Retirement System}

The social security salary shouldn't be misunderstood, it's not a retirement system but a supplement to it and it's a symbiotic system not only for the elderly people, but also for the patient, unemployed, disabled, unqualified, and maternity insurance. It also serves as a respect and appreciation for those who have made efforts and sacrificed their lives to build their homeland, and to the virtuous parents who raised the sons to become engineers, doctors, homeland employees, security personnel and armed forces, manufacturer, builder, farmer, nanny, teacher, and others; all in their place where the role of every citizen must not be minimized on the soil of this country.

The social security salary must be paid regardless of whether the citizen is a worker or not; and only as a reminder in most world countries this salary is an award and a gift from the savings of young participants to the elderly parents to give them income or additional aid to prevent them from asking others for help; at this age and it's not a substitute for the civil retirement salary.

Example on how social security system works in US (Department of Social Security-USA (2013))

\begin{tabular}{ccccc}
\hline \multicolumn{5}{c}{ Benefit Calculations } \\
\multicolumn{5}{c}{$\begin{array}{c}\text { Social Security Benefits Vs. 35 year "averaged" Salary } \\
\text { Percent of "AIME" Salary eligible for in Social Security, PIA, Benefits }{ }^{[31]}\end{array}$} \\
\hline $\begin{array}{c}\text { AIME Salary } \\
\text { per month }\end{array}$ & $\begin{array}{c}\text { Single } \\
\text { Benefits }\end{array}$ & $\begin{array}{c}\text { Married } \\
\text { Benefits }\end{array}$ & $\begin{array}{c}\text { Single } \\
\text { Benefits } \\
\text { @ age 62 }\end{array}$ & $\begin{array}{c}\text { Married } \\
\text { Benefits } \\
\text { @ age 62 }\end{array}$ \\
\hline$\$ 791$ & $90 \%$ & $135 \%$ & $68 \%$ & $101 \%$ \\
\hline$\$ 1,000$ & $78 \%$ & $117 \%$ & $58 \%$ & $88 \%$ \\
\hline$\$ 2,000$ & $55 \%$ & $82 \%$ & $41 \%$ & $62 \%$ \\
\hline$\$ 3,000$ & $47 \%$ & $71 \%$ & $35 \%$ & $53 \%$ \\
\hline
\end{tabular}




\begin{tabular}{lllll}
\hline$\$ 4,000$ & $43 \%$ & $65 \%$ & $33 \%$ & $49 \%$ \\
\hline$\$ 5,000$ & $40 \%$ & $60 \%$ & $30 \%$ & $45 \%$ \\
\hline$\$ 6,000$ & $36 \%$ & $54 \%$ & $27 \%$ & $41 \%$ \\
\hline$\$ 7,000$ & $33 \%$ & $50 \%$ & $25 \%$ & $32 \%$ \\
\hline$\$ 8,000$ & $31 \%$ & $46 \%$ & $23 \%$ & $35 \%$ \\
\hline$\$ 9,000$ & $29 \%$ & $44 \%$ & $22 \%$ & $33 \%$ \\
\hline$\$ 10,000$ & $28 \%$ & $42 \%$ & $21 \%$ & $31 \%$ \\
\hline$\$ 11,000$ & $23 \%$ & $34 \%$ & $17 \%$ & $26 \%$ \\
\hline$\$ 12,000$ & $21 \%$ & $32 \%$ & $16 \%$ & $24 \%$ \\
\hline$\$ 13,000$ & $19 \%$ & $29 \%$ & $15 \%$ & $22 \%$ \\
\hline
\end{tabular}

* Married spousal benefits may be reduced or eliminated if spouse receiving a government retirement. Spouse still eligible for Medicare. ${ }^{[32]}$

Maximum percent of salary received before Medicare or tax deductions.

Retirement benefits are calculated at full retirement ages.

Age 62 retirement benefits are assumed to be $75 \%$ of full benefits.

Approximately AIME salary $=90 \%$ present salary.

Approximate only, contact Social Security for more detailed calculations

\section{Method Used to Calculate the Social Retirement Salaries in USA:}

In the United States, people donate this award and gift to the charitable institutions and associations due to the fact that their real retirement is enough, where the retirement salaries levels are between $(\$ 35.000-\$ 400.000)$ a year, which depend on the amount of participants' salary and on the length of their service, while the social security salaries are between (700-3.000) dollar per month. This salary isn't like a civil retirement but it's a benefit and a merit for those who have reached the age of 60 or older, where the social security law gives them the right to the social security salary, whether if they were rich or poor.

\section{Method Used to Calculate the Social Retirement Salaries in Jordan:}

-The cumulative insurance assets since the establishment of social security corporation until the end of October, 2019 amounted to (17.25) billion JDs, while the cumulative insurance expenses for the same period amounted to (9.9) billion JDs, and as a result the institution reached financial insurance surpluses of (6.65) billion JDs .

-The investment fund's assets increased to be (10.98) billion JDs based on the initial financial statements as of December 31, 2019, with an increase of (790) million JDs from the beginning of the year and a growth rate of 7.8\%.

The Retirement or Old Age Salary:

An employee receives a retirement salary when he or she reaches the age of 60 for men or 55 years for women, with at least 180 work months or 15 years, which include (84) months of paid contributions or seven consecutive years, and in certain cases the retirement age can be extended to 65 years for men or 60 years for women, in order to increase the amount of old age salary or to extend his or her qualification to work at the institution.

Retirement Salary Calculation Equation: percentage of dues or merits for this category amounted to $2.5 \%$ of the average monthly income; for the last 60 work months or 5 years, and a maximum limit of not more than (1500) JDs according to the following formula: (2.5\% of the average income of the last five years of work* total number of monthly contributions $/ 12+(2 \%$ of the increased amount from the amount of (1500) JDs * total monthly contributions /12.((

Early retirement salary:

An employee can retire early before reaching the legal age mentioned above, provided that men are at least 50 years of age with 252 months of work; or 21 years that include 216 months of actual contributions; or 18 years, but women are 
required to receive an early retirement salary to be at least 45 years old with 228 months of work, or 19 years that include 180 months of actual contributions in the social security, or 15 years. In addition to at least 60 months of the last 10 years contributions for the work of employees at the occupations, which are classified as dangerous, there are other cases that Social Security Act specifies in detail where employee can receive an early retirement salary before reaching 50 years, depending on the number of contributions, sex, and their age on 1/1/2014.

Early retirement salary calculation formula: It uses the previous formula above in addition to the last 60 months of contributions, taking into consideration the age of beneficiary at the time of presenting application.

\section{Disability Salary:}

The disability or inability to work is required to be related to a work injury or work related-disease, and the employee will be under assessment to determine the disability rate by the central medical committee and the medical appeals committee to assess his or her case with total or partial disability, provided that he or she has at least 5 years or 60 months of contributions at the Social Security corporation which include 24 months of continuous work, or 2 years where after it employee can receive his salary from the social security within six months of the date of work stoppage.

Disability Salary Calculation Formula: In relation to the total disability, 50\% of the average monthly income is paid to the beneficiary in 36 months period for the first 1,500 JDs of profits, plus 30\% of the excessive amount from 1500 JDs, while the partial disability pays $75 \%$ of the total disability salary. In the old age settlement, the beneficiary of social security pays $10 \%$ of his or her average annual income for each year, and for a period of 10 years of contributions or $12 \%$ of average annual income for periods of (10-18) years, or $15 \%$ of the average annual income for more than 18 years of contributions.

\section{Monthly Deductions Proportion:}

The law requires from all institutions, whether its large or small, private or public to join the social security umbrella and includes all its employees in the service, in addition to providing the advantage of optional participation in the social security, therefore it deducts a monthly amount of employee salary at the private sector that amount to (7.5\%) of the total salary, while the employer pay twice this amount, or approximately (14.25\%) of the employee's total salary, and would be deposited into the employee's private account at the Social Security corporation, where employee's monthly benefit rate is $(21.75 \%)$, with the fact that minimum wages covered by social security must not be less than 190 JDs.

While at the public sector's, the monthly deduction rate is $(19.5 \%)$ divided into $(6.5 \%)$ deducted each month from the total salary of employee, while the institution or ministry pay (13\%) of the employee total monthly salary. Therefore the employee will carry $(1 \%)$ of his or her total monthly salary compared with $(2 \%)$ that employer pay, whether at the private or public sector of the monthly employee total salary .

\section{Optional Participation:}

The monthly due amount that optional participants must pay to the Social Security corporation is (17.5\%) of their total monthly salary subject to the social security deductions, and this ratios which was passed by the Social Security Act, 2017 is the latest update on the law that currently implemented in Jordan .

\section{Questions and Restraints about the Social Security Act:}

First Question: countries that implement the social security system in different part of the world as a comprehensive system for all those who have reached an old age regardless of the fact that participation in it consider a right for all, where the salary of social security beneficiaries increases with the increase in the amount and length of contribution, but the security laws of those countries give all those who have reached an old age a salary that guarantee them to live without asking anyone for help. Unfortunately, we see many sad cases of elderly who have no main source of income and who don't find even a small amount of money to remain under the mercy of benefactors. Is this the way to reward and repay our fathers and mothers after they gave their lives to build the country and raise the generations, where one day all of us will be in the same situation or worse therefore we must take brave and serious steps, and correct this imbalance in the Social Security Act, in order to give those old people and who have reached the old age; regardless if they were registered or not the fair salary that is enough for them to live decently. In regard to the amount of participants' salary, it's okay for it to increase according to the period and amount of participation.

Second Question: Why doesn't retirement salaries be separated from the salaries of social security and re-implemented? It's the right of employees that intended to do several things, such as taking care of employees at old age, secure salaries for the natural disability, work injury, maternity, unemployment, and the natural death or those resulting from work injuries. There is injustice and unfairness in relation to employees and retirees rights at the various participant 
sectors in Jordan, especially after the government put an end to the civil retirement system in 1995, where it was completely suspended and replaced by the social security retirement system for 2003, without reviewing it or making it available for the civil, labor, and human rights institutions .

Third Question: Why there is more than one retirement system at place in Jordan?

Fourth Question: is the salary of social security beneficiaries sufficient for life expenses, and is it enough to cover the cost of living? Its known that social security is a social symbiotic system found to provide assistance to the elderly, the family of deceased, the disabled, the work injuries, and the unemployed. Why did it become a basic retirement salary and other pensions' salaries were cancelled for it? This means that there is no other option or source of income for this retiree, since these salaries are the only source of income for those citizens of this category, which has no power. If these salaries and incomes weren't enough, shouldn't the salaries of social security beneficiaries be improved? Who is responsible for raising the salaries of this group? If the state requires legal legislation, what is the reason for issuing such a law? Why doesn't the wage system at all work sectors in Jordan not linked with the overall level of prices and average cost of living? It should be adjusted annually by the rate of increase in the overall level of prices after the establishment of a wage base, where the least of it will be the sufficient limit to level of monthly living cost for a family of 5 .

Fifth Question: Who is responsible for determining the salaries' levels in social the security? If the state is responsible, why doesn't unify a salary systems for all state institutions, as well as the salary scale in social security, public and private sectors, the army and security, and others to create wage's base that stand on correct scientific foundation and used in the division of allowances, categories, and degrees where in it the wage base is the average cost of living, and then the other allowances, such as specialty allowance, educational degree, family allowance, and inflation .

Sixth Question: If all these distortions in the various state wage systems, and most of it are low and don't reach the minimum wage or even the poverty line set by the state, in addition to the fact that all of it don't reach the sufficiency limit of average cost of living, which turned out to be (854) JDs per month for the Jordanian family based on the department of General Statistics reports of expenditure costs averages for 2016, and this figure doesn't have any comfort or luxury and isn't even sufficient for the basic cost of living.

Investment Fund:

Social Security Investment Data:

Based on the statements of Investment Fund Chairman and the Social Security Corporation reports (2018-2019):

-The investment fund's assets increased to (10.98) billion JDs based on the initial financial statements as in December 31,2019 , up by (790) million JDs from the beginning of the year with a growth rate of (7.8\%.)

-The fund's preliminary financial results for 2019 indicate that investment fund continued to achieve positive results in 2019, by achieving an income of (559) million JDs compared with(434) million JDs; for the same period of 2018 with a growth rate of about $29 \%$. These returns came mainly from the cash distributions of participating companies, as well as investment returns in the fixed income tools, leasing loans, and the real estate investments.

\section{Social Security Investment Fund for 2019:}

-The Investment Fund expanded its real estate investments during 2019 through the purchase of several properties in various provinces of the Kingdom, with an estimated value of (70) million JDs, in order for the total value of real estate portfolio to become about (667) million JDs at the end of 2019, in addition to the value growth of leasing a number of those lands and real estate. Profits resulting from increase in the value of total real estate portfolio compared with the cost of purchasing it exceeded (126) million JDs.

-The Investment Fund has increased its investments in a number of public shareholding companies that are characterized by the strength of its financial ranks, and do distribute continuous annual profits, the most important of those are Arab Bank where its contribution ratio became about (17\%) of the bank's capital, Union Bank with a contribution of (8.4\%) of the bank's capital, Safwa Islamic Bank with a contribution of (9.1\%) of the bank's capital, and finally the Islamic Bank of Jordan with a contribution of (5.8\%) of the bank's capital.

-The Investment Fund also invested in the bond's portfolio, where the returns value of entire bond portfolio reached about (345) million JDs, at the end of 2019 with a return rate of (5.9\%), which consider one of the highest return rates that were achieved by the investment instruments invested by the Investment Fund compared with the low level of risk associated with it. In addition, it started during October, 2019 the rehabilitation of Crown Plaza Hotel-Petra, which expected to reopen for visitors in the middle of next year . 
-In 2019, the Investment Fund signed agreements to build three solar power plants to feed the hotels owned by the General Social Security Corporation and its branches, in addition to the Investment Fund building with a capacity of (15) Megawatts. The operation of these stations will result in an annual savings of about (7) million JDs in the expenses of General Social Security Corporation. It's expected that the Investment Fund will recover the project costs within three years, and the operation of stations will start during the first half of this year.

-Investment Fund continued to finance major vital projects in various regions of the Kingdom through the financial leasing in health, transport, and services sectors, such as Amman-Al-Madounah Customs Building Project, Maan Military Hospital Project, Al-Tafila Hospital Project, and the Fast Frequency Bus Project, which will connect between the cities of Amman and Zarqa. Investment Fund is also conducting some studies to finance Madaba Hospital Project and several health centers in the Kingdom.

-As part of the Investment Fund's participation approach, a number of understanding memorandums were signed for the purposes of exchanging experiences, where the Investment Fund conduct studies to establish new investment projects in vital sectors, and signed an understanding memorandum with the Palestinian Retirement Authority, Government Investment Management Company (formerly Government Contribution Management Company), Investment Authority, Meridian Company/Jordan, and the Islamic Endowments Department/Ministry of Islamic Affairs and Holy Places.

It also signed memorandums of understanding with the Ministry of Tourism, Tourism Promotion Authority, Investment Authority, and the Royal Society for Protection of Nature. In addition, the Investment Fund signed memorandum of understanding with the Ministry of Tourism, the Investment Authority, the Tourism Promotion Authority, and the Royal Society for the Protection of Nature. Al-Saqqaf explained that in 2019 the Investment Fund issued a tutorial guide to represent the General Social Security Corporation on the boards of companies that corporation make contribution to it .

-The Investment Fund also grants upper limit funds for the General Social Security Corporation for the purposes of financing personal advances and also advances for the development of small projects that exist for the general social security corporation retirees, which currently has a balance of (70) million JDs where the beneficiaries of these advances have exceeded $(28,000)$ at the end of last year.

-During the strategic plan of (2019-2021), the Investment Fund aims to study many new sectors to invest in, which include education and the medical sectors and it also aims to expand some of the existing sectors or investments, such as the infrastructure projects and the public-private partnership projects to achieve meaningful returns to the Investment Fund within acceptable risk levels, taking into account the role of projects to motivate economic growth and sustainable development dimension.

There are different ratios of disparity in the average figures of retirement's salaries, wages, and the number of beneficiaries from different categories, due to the differences in the numbers between different government sources, such as the Department of Public Statistics, Social Security Corporation, Ministry of Labor, and other sources. The study selected the most important and accurate figures, according to the available potentials, capabilities, and information. The study also faced some difficulties in collecting information related to the calculation of retirements salaries; for the different categories as well as information related to the investment fund, its assets, types of investments, and the returns on investments, knowing that the researcher made an effort in this study to collect and analyze all the available information, check its accuracy, and provide the best results and recommendations as much as possible.

\section{Results \& Discussion}

General Digital Statistics until 2018

\begin{tabular}{ll}
\hline Total population & 9.559 .000 (millions) \\
\hline Number of people covered by the social security system & 1.166 .000 (millions) \\
\hline Percentage of those covered by the security system from the total population & $12.00 \%$ \\
\hline Number of people aged (+64) who aren't covered by the security system & 353.683 (thousands) \\
\hline Population numbers who aren't covered by the social security system & 8.393 .000 (millions) \\
\hline Population under 15 yrs & 3.278 .737 (millions) \\
\hline
\end{tabular}




\begin{tabular}{ll}
\hline Percentage of population under 15 years of age & $34.3 \%$ \\
\hline Population (15-64) years & 5.926 .580 (millions) \\
\hline Percentage of population age (15-64) & $62.0 \%$ \\
\hline Percentage of population age (+64) & $3.7 \%$ \\
\hline Number of people not covered by social security (+64) & 353.000 (thousands) \\
\hline Number of working and insured Jordanians in the social security & 1.200 .000 (millions) \\
\hline Total salaries of participants and insured employees in the social security & 575.514 .429 (millions) \\
\hline Number of non-Jordanians who work and insured in the social security & 135.948 (thousands) \\
\hline Total wages of Jordanian employees insured in the social security & 538.447 .55 (millions) \\
\hline Total salaries of non-Jordanian employees insured in the social security & 37.066 .872 (millions) \\
\hline Average salary rate of retirees who are subject to social security provisions & 503JD a month \\
\hline Average salaries of social security beneficiaries & 576JD a month \\
\hline
\end{tabular}

General Statistics Service and Social Security Corporation Reports 2015/16

\section{The analysis results of the table above:}

- 88\% of Jordan's population is not participating or benefiting from the social security system (5.926.580) millions.

- Only $12 \%$ of Jordan's population benefits from the social security system $(1,166,000)$ millions.

- Only $0024 \%$ of the population covered by the social security wage system aged +61 years (2847).

- 3.7\% of those aged $(+64)$ of the total population are not covered by the social security system $(353,683)$.

- Total wages of insured employees in the social security (538.447.872) million JDs.

- Average wages of social security employees (503) JDs a month.

- Average salaries of social security beneficiaries (291) JDs a month.

Salary and Wage Divisions According to the Official Jordanian Government Agencies until (2014/2015)

\begin{tabular}{lccc}
\hline \multicolumn{1}{c}{$\begin{array}{l}\text { Wage Type } \\
(1)\end{array}$} & $\begin{array}{l}\text { Average } \\
\text { monthly yearly } \\
\text { wage until } \\
2014 / 2015(2)\end{array}$ & $\begin{array}{l}\text { Average monthly cost } \\
\text { of living-family } \\
\text { allowance rule until } \\
\text { 2014/2015 (3) }\end{array}$ & $\begin{array}{l}\text { Difference between the } \\
\text { sufficiency limit and the } \\
\text { nominal wage (due increase) } \\
\text { per worker (3-2) = (4) }\end{array}$ \\
\hline Minimum wage & 220 & 854 & 634 \\
\hline Poverty line & 339 & 854 & 515 \\
\hline $\begin{array}{l}\text { Average pay at public and } \\
\text { private sector }\end{array}$ & 469 & 854 & 565 \\
\hline $\begin{array}{l}\text { Average salary of the Social } \\
\begin{array}{l}\text { Development Ministry and the } \\
\text { National Aid Fund }\end{array}\end{array}$ & 293 & 854 & 351 \\
\hline $\begin{array}{l}\text { Average retirement salaries for } \\
\text { social security participants }\end{array}$ & 503 & 854 & 515 \\
\hline $\begin{array}{l}\text { Average salaries of social } \\
\text { security beneficiaries }\end{array}$ & 339 & 854 & \\
\hline
\end{tabular}

* Salary and wage divisions according to the official Jordanian government agencies until 2014/2015

\section{The analysis results of the table above:}

- The lowest wage estimated by the Jordanian government as a minimum wage of (220) JDs monthly salary.

- The average salary of security participants according to the social security corporation amounted to minimum wage of (503) JDs per month.

- The average salary of social security beneficiaries amounted to (339) JDs per month. 
- There is a contradiction and imbalance in the divisions of monthly salary amount and there is no rule to determine the wages, such as the sufficient wage based on the approved cost of living averages, which is estimated at (854) JDs per month for the Jordanian family of 5 members.

Table of the average family annual cost of living according to the Jordanian family expenditure groups as a base for the adequate or fair pay, the official government statistics (2006-2013)

\begin{tabular}{lcccc}
\hline Expenditure Type & Year & Year & Year & Year \\
\hline Food Stuffs & 2006 & 2008 & 2010 & 2013 \\
\hline Cigarettes \& Tobaccos & 2485 & 3205 & 3388 & 3499 \\
\hline Clothing \& Shoes & 270 & 340 & 426 & 481 \\
\hline Housing \& Accessories & 372 & 346 & 339 & 306 \\
\hline Transportation \& Communications & 2014 & 2106 & 2455 & 2870 \\
\hline Education & 1191 & 1450 & 1650 & 1813 \\
\hline Health care & 529 & 161 & 549 & 570 \\
\hline Personal care & 204 & 161 & 212 & 214 \\
\hline Culture, Entertainment \& Sports & & 258 & 293 & 70 \\
\hline Other consumer expenses & 119 & 78 & 127 & 70 \\
\hline \multicolumn{1}{c}{ Total } & 104 & 131 & 183 & 141 \\
\hline $\begin{array}{l}\text { Cost of living average for the Jordanian family } \\
\text { (Sufficiency wages rule) }\end{array}$ & 7521 & 8516 & 9626 & 10251 \\
\hline
\end{tabular}

*Family Expenditure Survey Report, General Statistics Service (2006-2013)

\section{The analysis results of the table above:}

- The average cost of living or annual expenditure for the Jordanian family on the goods group amounted to $(10,251)$ JDs or (854) JDs per month.

- $34 \%$ of the total expenditure on food stuffs.

- $27 \%$ of the total expenditure on housing \& its accessories.

- $17 \%$ of the total expenditure on transportation and communications.

- Only $2 \%$ on health care.

- Only $5 \%$ on education.

This means that most households spending are only on the basics or necessities.

\section{Wage system for participants and beneficiaries of Jordanian social security:}

The pay and wage system specify the participating employees in it, according to certain rules where the pay shouldn't be less than the minimum wage which set at $(220)$ JDs per month with a maximum of $(3,000)$ JDs according to a range of categories and according to the economical activity, which depend on the average monthly wage, age, and the service lengths.

First: Table of insured employees (participants) according to sex, nationality, total wages, average monthly wage, and the economical activity for 2015

\begin{tabular}{lccc}
\hline Economic Activity & Number & $\begin{array}{c}\text { Average Monthly } \\
\text { Salary }\end{array}$ & $\begin{array}{c}\text { Total monthly } \\
\text { salaries per sector }\end{array}$ \\
\hline Agriculture Sector & 4.776 & 373 & 1.781 .448 \\
\hline Industrial Sector & 168.537 & 319 & 53.763 .303 \\
\hline Commercial Sector & 103.532 & 434 & 44.907 .005 \\
\hline
\end{tabular}




\begin{tabular}{lccc}
\hline Construction Sector & 40.166 & 501 & 20.123 .166 \\
\hline Transportation Sector & 34.242 & 653 & 22.360 .026 \\
\hline Banking \& finance sector & 31.262 & 927 & 28.995 .505 \\
\hline Tourism Sector & 43.207 & 366 & 15.813 .762 \\
\hline Other Services & 665.331 & 537 & 357.492 .738 \\
\hline Unspecified & 69.024 & 605 & 41.759 .520 \\
\hline $\begin{array}{l}\text { Average Salaries of all } \\
\text { Participants }\end{array}$ & $\mathbf{1 . 1 6 6 . 9 9 1}$ & $\mathbf{5 0 3}$ & $\mathbf{5 8 6 . 9 9 6 . 4 7 3}$ \\
\hline
\end{tabular}

* Social Security Corporation and General Statistics Department reports (2015-2019)

The analysis results of the table above:

- The Jordanians accounted for $86 \%$ of the total social security participants and $14 \%$ for non-Jordanians.

- Average salary of Jordanians (522) JDs per month and non-Jordanians (272) JDs per month.

- Average monthly salary for participants (503) JDs.

- The tourism sector had the lowest income with an average salary of (366) JDs.

- The industrial sector salaries had the lowest minimum monthly wage of (319) JDs, which is less than the poverty line salary of (339) JDs.

- The banking \& financial sector had the highest income with an average salary of (1010) JDs per month.

Second: Categories and average retirement's salaries of beneficiaries, and the rate of deserved increase to arrive to the sufficiency wage for those who currently receive salaries from the social security until 2015/2016

\begin{tabular}{|c|c|c|c|c|c|}
\hline Category & Number & $\begin{array}{c}\text { Average monthly } \\
\text { retirement salary } \\
\text { of beneficiaries } \\
\text { (1) }\end{array}$ & $\begin{array}{l}\text { Monthly sufficiency } \\
\text { limit according to } \\
\text { the cost of living } \\
\text { averages for the } \\
\text { Jordanian family (2) }\end{array}$ & $\begin{array}{l}\text { Difference between } \\
\text { sufficiency limit and } \\
\text { nominal wage (due } \\
\text { monthly increase) } \\
\text { per worker }(3)=(1-2)\end{array}$ & $\begin{array}{l}\text { Total due } \\
\text { increase to } \\
\text { arrive to } \\
\text { sufficiency limit } \\
(\text { Emp No. *3) }\end{array}$ \\
\hline $\begin{array}{l}\text { Natural disability } \\
\text { retirement salaries }\end{array}$ & 9825 & 268 & 854 & 586 & 5.757 .450 \\
\hline $\begin{array}{l}\text { Injury disability } \\
\text { retirement salaries }\end{array}$ & 2937 & 164 & 854 & 690 & 2.026 .530 \\
\hline $\begin{array}{l}\text { Mandatory old } \\
\text { age retirement } \\
\text { salaries }\end{array}$ & 60.384 & 621 & 854 & 233 & 14.069 .472 \\
\hline $\begin{array}{l}\text { Early aging } \\
\text { retirement salaries }\end{array}$ & 89.342 & 427 & 854 & 424 & 37.881 .008 \\
\hline $\begin{array}{l}\text { Natural death } \\
\text { retirement salaries } \\
\text { for inheritor }\end{array}$ & 15.788 & 348 & 854 & 548 & 8.651 .824 \\
\hline $\begin{array}{l}\text { Injury death } \\
\text { retirement salaries }\end{array}$ & 2.924 & 439 & 854 & 415 & 1.213 .460 \\
\hline $\begin{array}{l}\text { Natural disability } \\
\text { retirement salaries }\end{array}$ & 8543 & 259 & 854 & 595 & 5.083 .085 \\
\hline $\begin{array}{l}\text { Injury disability } \\
\text { retirement salaries }\end{array}$ & 431 & 171 & 854 & 683 & 294.373 \\
\hline $\begin{array}{l}\text { Mandatory aging } \\
\text { death retirement } \\
\text { salaries } \\
\end{array}$ & 13.641 & 232 & 854 & 622 & 8.484 .702 \\
\hline Early aging & 6.018 & 616 & 854 & 238 & 1.432 .284 \\
\hline
\end{tabular}


retirements

salaries

\begin{tabular}{lccccc}
\hline $\begin{array}{l}\text { Injury morbidity } \\
\text { retirement salaries }\end{array}$ & 4.122 & 178 & 854 & 238 & 981.036 \\
\hline $\begin{array}{l}\text { Natural morbidity } \\
\text { retirement salaries }\end{array}$ & 21.203 & 348 & 854 & 506 & 10.919 .545 \\
\hline
\end{tabular}

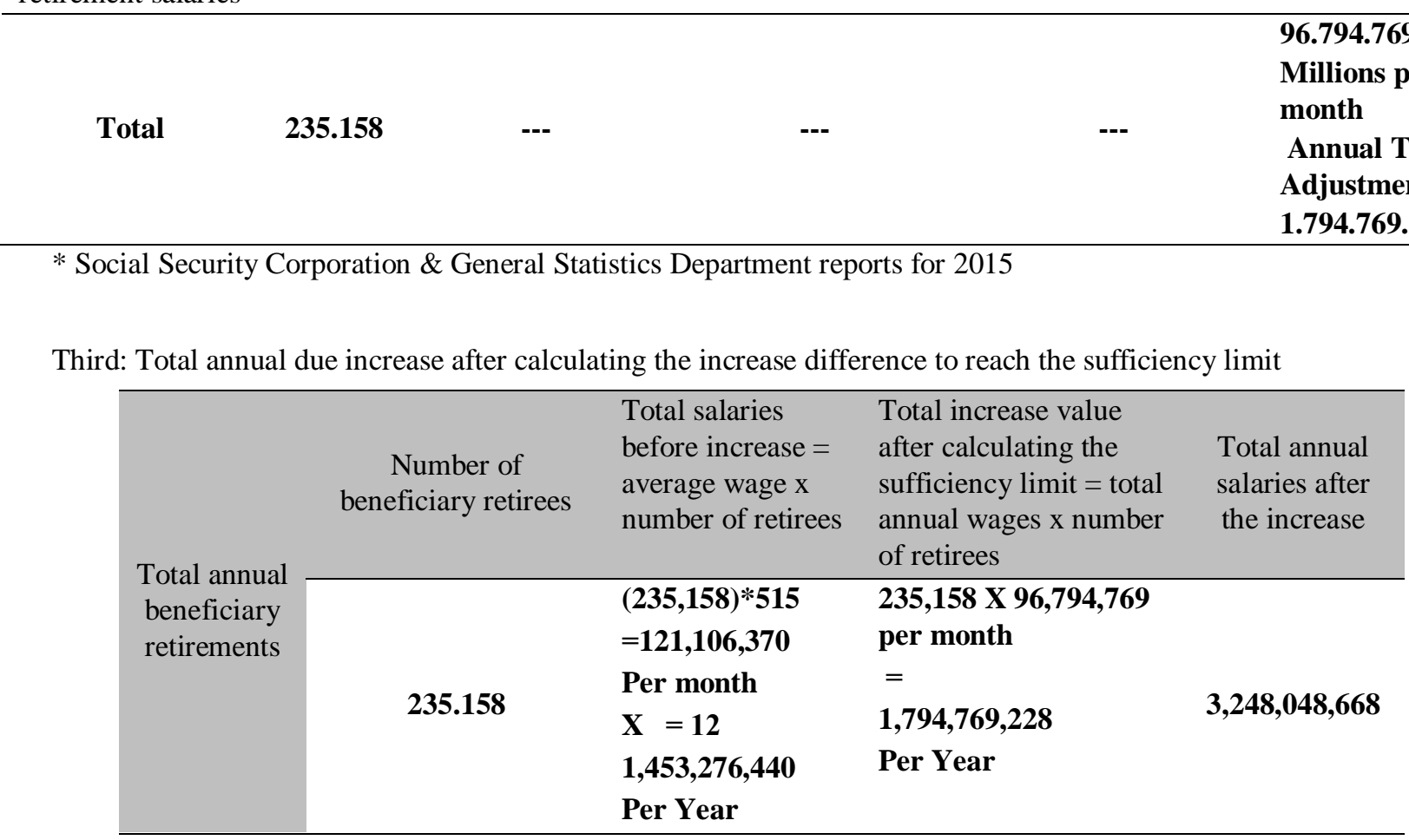

The analysis results of the two tables above:

- The minimum wage for the disability retirement salaries amounted to (164) JDs

- The highest wage for mandatory old age retirement salaries amounted to (621) JDs

- Average wages for the retirees' beneficiaries' salaries amounted to (339) JDs

- Cost of living averages for a family of five amounted to about (854) JDs per month

- The adopted poverty line for the average Jordanian family is (339) JDs per month

- $26 \%$ of social security salary beneficiaries receive salaries less than (339) JDs, which means that $26 \%(38,456)$ of the total beneficiaries of the social security retirement salaries $(235,158)$ are below the poverty line

- All beneficiaries of the social security salary are below the sufficiency limit, where the sufficiency limit for cost of living average is (854) JDs which means that $100 \%$ of social security retirees are below the limit

- All salaries of the social security beneficiaries don't reach the sufficiency limit which amount to (854) JDs per family, according to the cost of living average, and according to the statistics of General Statistics Department

- The minimum wage set by the state is 220 per month, which means that 2.937 people receive a monthly salary of 164 JDs and 431 receive a salary of 171 JDs. This means that 13.641 people receive a monthly salary of 232 JDs, which is closer to the minimum wage

- $12 \%$ of the social security beneficiaries' salaries are below the poverty line, or $(17,009)$ people out of the overall beneficiaries (147.908).

- Total annual salaries of beneficiaries' retirees amounted to (1.453.276.440) JDs

- The total due increase on the annual salaries of beneficiaries to arrive to the sufficiency wages amounted to (1.794.769.228) JDs 
- The total due salaries to beneficiaries after the addition of sufficiency wages difference amounted to (3.248.048.668) JDs

Fourth: Average salaries of employees by category and the increase due amount reach fair or sufficiency wages, according to the activity in social security Corporation until 2017

\begin{tabular}{|c|c|c|c|}
\hline Economic Activity & $\begin{array}{l}\text { Monthly Nominal } \\
\text { Wage (2) }\end{array}$ & $\begin{array}{l}\text { Monthly Sufficiency } \\
\text { Limit ( 3) }\end{array}$ & $\begin{array}{l}\text { The difference between the } \\
\text { sufficiency limit and the } \\
\text { nominal wage (due increase) } \\
\text { per worker } 4=(3-2)\end{array}$ \\
\hline Agriculture Sector & 414 & 854 & 440 \\
\hline Industrial Sector & 379 & 854 & 475 \\
\hline Commercial Sector & 434 & 854 & 420 \\
\hline Construction Sector & 498 & 854 & 356 \\
\hline $\begin{array}{l}\text { Transportation, } \\
\text { telecommunication, } \\
\text { and storage sectors }\end{array}$ & 683 & 854 & 171 \\
\hline $\begin{array}{l}\text { Banks, Finance \& } \\
\text { Banking, \& } \\
\text { Brokerage Sector }\end{array}$ & 1010 & 854 & 0 \\
\hline $\begin{array}{l}\text { Defense and Public } \\
\text { Administration }\end{array}$ & 458 & 854 & 396 \\
\hline Education & 517 & 854 & 337 \\
\hline $\begin{array}{l}\text { Health and Social } \\
\text { Work }\end{array}$ & 545 & 854 & 309 \\
\hline Public Sector & 469 & 854 & 385 \\
\hline Private Sector & 494 & 854 & 360 \\
\hline $\begin{array}{l}\text { International } \\
\text { Organizations \& } \\
\text { Institutions }\end{array}$ & 970 & 854 & 0 \\
\hline $\begin{array}{l}\text { Charitable } \\
\text { Associations }\end{array}$ & 606 & 854 & 248 \\
\hline Tourism Sector & 376 & 854 & 488 \\
\hline Other Services & 488 & 854 & 366 \\
\hline Unspecified & 605 & 854 & 249 \\
\hline Average Wages & 559 & 854 & 295 \\
\hline $\begin{array}{l}\text { Average wages of } \\
\text { mandatory insured }\end{array}$ & 493 & 854 & 361 \\
\hline $\begin{array}{l}\text { Average wages of } \\
\text { optionally insured }\end{array}$ & 668 & 854 & 186 \\
\hline $\begin{array}{l}\text { Overall average for } \\
\text { all insured retirees }\end{array}$ & 559 & 854 & 295 \\
\hline
\end{tabular}

*Annual report of average wages of social security participants and average salaries of beneficiaries according to the economic activity (2012-2019)

\section{The analysis results of the table above:}

- Average salaries of security participants amounted to (559) JDs per month.

- The industrial sector received the lowest wage with a monthly rate of (379) JDs.

- The salaries of financial sector and banks reached the highest with an average of (1010) JDs per month. 
- $89 \%$ of social security participants salaries are below the sufficiency limit of (854) JDs per month.

- All the salaries of industrial sector participants who amounted to 168.537 employees receive an average salary of (379) JDs below the poverty line, which was set by the state at (339) JDs per month.

\section{Conclusion \& Recommendations}

Study concludes the following:

-The retirement system of social security beneficiaries isn't base on real studies of the average living costs level of Jordanian household of five individuals as a minimum, or the applicable salary and wage allowances in the international labor laws.

-The civil pension system was cancelled in 2003 and all public sector employees were forced to participate in the social security retirement system, which is a violation of the international labor laws.

-Social security participants don't benefit from the achieved profits of the Social Security Participants' Money Investment Fund, and there is government interference in the policies and management of social security corporation funds, and with that the government will be violating the laws and regulations.

-There are distortions in the salary and wage system of Jordan between the different sectors, such as the private sector, the government, the army or military, and the various security agencies. There are also distortions in the minimum wage, the poverty line, and the standard of living costs for the Jordanian family.

Study made the following recommendations:

-The establishment of a higher wage council made up of economists, jurists, financial people, and representatives from the public and private sector, and the army, military, and security institutions to establish a fair wage system.

- The creation of a fair pay system that takes into account the cost of living, inflation rates, and other increases, which will be developed by the higher wage council and calculate the wages based on fair and unified scientific rules and concepts for all sectors where the decisions of this council will be mandatory for all, and the law will punish anyone who fails or refuses to abide by it.

-Civil pension system must be restored, due to the fact that it's based on hard work, effort, tiredness, and service of employees, where the public and private institutions must be obliged to implement the law in the same way as international labor laws.

-The social security retirement system for the elderly is a right of every Jordanian citizen who holds the national number and isn't an alternative to the civil pension system, and also it's not a substitute or supplement for any other salary taken by the citizen, but it's only an assistance to the citizen who has reached the old age.

-The method used to calculate salaries of retirement beneficiaries and participation beneficiaries of social security is unfair, where the person loses more than half of the salary he or she was receiving during his employment which leads to suffering and poverty of citizen, especially since the government canceled the civil pension system therefore retirees now have no source of income except the very low social security retirement salaries, which in some cases doesn't reach the poverty line.

- Restoring civil pension salary and activating the Investment Fund Reserve System, where all the employees should benefit from the profits achieved during the service period, and added to their savings.

- It must be an independent supervision on social security Corporation, accountability of violators, and the prevention of abuse on this institution by some of the influential individuals in the state and social security managers.

- Some social security regulations and laws must be modified and amended to be more equitable, especially the retirement salaries calculation formula to be equivalent with the living costs level.

- The retirement salaries systems must be standardized for all state institutions and formulate a fair salary scale that include the social security, public and private sectors, army and security, and others where the wages base will depend on a correct scientific principles and rules that is fair in the division of allowances, categories, and ranks where the base wages in it will be the average cost of living, and then the other allowances, such as specialty allowance, degree, and family and inflation allowance.

- The civil pension system for employees must be separated from the retirement system of social security for elderly, and the civil pension system must be re-implemented in the same way it's implemented in all world countries.

- The study recommended establishing a higher wage council which will be responsible for conducting analytical studies that aimed to unify the wages system and the salaries of all retirees' categories in Jordan, where the retirement 
salaries of social security beneficiaries are equal to the retirees' salaries of the public sector, private sector, defense, and security. The base of retirements salaries also should not be less than the cost of living averages, which amounted to (854) JDs per month for the Jordanian family of five, and to search for the financial resources to achieve this goal by exploiting Jordan's inoperative resources, and by not relying on borrowing from the international corporations or on taxes.

\section{References}

[42 USC 7] "US Code-Title 42-The Public Health and Welfare". Archived from the original on October 12, 2006, Retrieved November 8, 2006.

A press meeting with the director of Investment Fund at the Jordanian Social Security, Khlood Al-Saqqaf. Al-Ghad Jordanian newspaper (20/02/2020).

A Reader's Companion to American History: Poverty. Archived from the original on February 10, 2006, retrieved June 28, 2016.

A Summary of the 2016 Annual Reports. Social Security \& Medicare Boards of Trustees.

Abu Al-Fatouh, \& Najah Abdul Aleim. (2010). Islamic Economy System and Theory. Book World, Irbid, Jordan, pp. $46-47$

Al-Samadi, \& Mustafa Mohammed Suleiman. (2012). Linking wages in the public sector with sufficient limit from an Islamic economic perspective (The Case of Jordan). Ph.D. dissertation, Yarmouk University, Irbid, Jordan.

An Article of the Association of Social Security Retirees that demanding for better salaries of social security retirees. All Jordan News Website, Amman, 2013.

Arno, T. (2003). Editor of The Three Pillars of Wisdom, A Reader on Globalization. World Bank Retirement Models $\&$ Welfare Society, Nova Science Hauppauge, New York.

Arun, M., \& Serge, A. (Eds.) (2005). Reforming European Retirement Systems. Amsterdam, NL and West Lafayette, Indiana, USA, Dutch University Press, Rozenberg Publishers \& Purdue University Press.

Book of Jordanian Social Security Law, Social Security Corporation of Jordan, Amman, Jordan, 2014.

Center on Budget and Policy Priorities, Social Security Keeps 22 Million Americans Out of Poverty: A State-By-State Analysis, updated October 25, 2016.

Contribution and Benefit Base. Social Security Administration, retrieved November 30, 2017.

Department of General Statistics - Unemployment rate during the third quarter of 2019.

Devereux, S., \& Sabates-Wheeler, R. (2007). Debating Social Protection' IDS, Bulletin 38 .3. Brighton: Institute of Development Studies.

General Statistics Department Reports (2003-2018).

Hassan, A. (2002). Wage Theory in the Islamic Jurisprudence. Dar Iqraa, Syria, I1.

Law of the Second New Deal was the Social Security Act, signed into law by President Franklin D. Roosevelt on August 14, 1935.

Ministry of Development Reports (2003 - 2019).

Ministry of Labor Reports (2003-2019).

Modigliani, F. (2004). Rethinking retirement reform. Franco Modigliani, Arun Muralidhar, Cambridge, UK, New York, Cambridge University Press.

Morton, W. R., \& Liou, W. (2017, September 12). Social Security: The Trust Funds (PDF). Washington, DC: Congressional Research Service, retrieved 16, Oct., 2017.

Muralidhar, A. S. (2001). Innovations in retirement fund management. Arun S. Muralidhar, Stanford, Calif., Great Britain, Stanford Economics \& Finance.

Peter, M. (2009). Amazon.com, 5- When the Public Works: Generating Employment and Social Protection in Ethiopia. Lambert Academic Publishing.

Rababah, Adnan Mohammed Yusuf. (1999). Wage Theory in Islamic Economy. Yarmouk University, Irbid, Jordan, pp. 49-53. 
Reports by Social Security of Jordan, Social Security Corporation, seen on 6, Feb., 2019.

Reports submitted for participation performance, Social Security Corporation, seen on 6, Feb., 2019.

Shadi, H. (2003, August). An Islamic Alternative? Equality, Redistributive Justice, and the Welfare State in the Caliphate of Umar. Renaissance: Monthly Islamic Journal, 13(8).

Social Security \& Medicare Tax Rates. Social Security Administration, retrieved Nov. 30, 2017.

Social Security Act of 1935. Legislative History 1935 Social Security Act, retrieved Nov. 8, 2006.

Social Security Administration. Social Insurance Programs, retrieved November 1, 2016.

Social Security FAQ [2] accessed 2, Feb, 2017.

Social Security History [1] accessed 7, Nov, 2013.

Social Security Programs throughout the World: Asia and the Pacific, 2016. Social Security Programs, Jordan Social Security and Welfare. Retrieved June 2, 2019, from www.expatfocus.com

Social Security Service department Reports (2003-2019).

The Effects of Financial and Economic Crisis on the Jordanian Economy. National Conference for Reform, Jordan, Amman, 2010.

United States Social Security Administration. Contribution and Benefit Base.

Zubair, M. O. (1976). The Role of State in Achieving the Goals of Islamic Economy. Islamic Institute for Development, 13-16. 